\title{
APLIKASI METODE GEOLISTRIK RESISTIVITAS KONFIGURASI WENNER-SCHLUMBERGER UNTUK MENGIDENTIFIKASI LITOLOGI BATUAN BAWAH PERMUKAAN DAN FLUIDA PANAS BUMI WAY RATAI DI AREA MANIFESTASI PADOK DI KECAMATAN PADANG CERMIN KABUPATEN PESAWARAN PROVINSI LAMPUNG
}

\author{
Wilyan Pratama ${ }^{1}$, Rustadi ${ }^{2}$ \\ 1,2,Jl. Prof. Dr. Sumantri Brojonegoro No.1, Bandar Lampung 35145 \\ Jurusan Teknik Geofisika, Fakultas Teknik, Universitas Lampung \\ Corresponding author: wilyanp37@gmail.com \\ Manuscript received: June 21, 2018; revised: August 22, 2018; \\ Approved: November 29, 2018; available online: March 1, 2019
}

\begin{abstract}
Abstrak - Daerah penelitian terletak di Kecamatan Padang Cermin Kabupaten Pesawaran Provinsi Lampung. Manifestasi di area penelitian berbentuk kolam air panas dengan suhu permukaan mencapai $90^{\circ} \mathrm{C}$. Akusisi data pengukuran dilakukan dengan konfigurasi Wenner-Schlumberger berjumlah 5 lintasan. Lintasan 1, lintasan 4 serta lintasan 5 memiliki panjang lintasan 280 meter. Lintasan 2 memiliki panjang lintasan 240 meter dan lintasan 3 memiliki panjang lintasan 320 meter dengan spasi elektroda setiap lintasan pengukuran yaitu 5 meter. Penelitian ini bertujuan (1) Meneliti kandungan geokimia dan jenis fluida, (2) Mengidentifikasi fluida panas bumi berdasarkan analisis data resistivitas 2D dan 3D dan (3) Mengidentifikasi lapisan batuan manifestasi Padok berdasarkan penampang bawah permukaan resisistivitas 2D dan 3D. Litologi batuan bawah permukaan daerah penelitian secara umum dibagi menjadi 4 bagian yaitu fluida air panas memiliki nilai resistivitas rata-rata $1 \Omega \mathrm{m}$ sampai dengan $3 \Omega \mathrm{m}$. Berdasarkan data geokimia jenis fluida daerah penelitian adalah air klorida. Nilai resistivitas $6 \Omega \mathrm{m}$ sampai dengan $50 \Omega \mathrm{m}$ diidentifikasik sebagai endapan permukaan diantaranya endapan rawa, dan endapan alluvium terdiri dari kerakal, kerikil, pasir, lempung, dan gambut. Nilai resistivitas $50 \Omega \mathrm{m}$ sampai dengan $100 \Omega$ m diidentifikasi sebagai kerakal, kerikil, pasir dan lempung. Batuan lava (andesit-basalt) memiliki nilai resistivitas diatas $100 \Omega \mathrm{m}$.
\end{abstract}

\begin{abstract}
Abtsract - Research area is located in Padang Cermin Sun-District, Pesawaran Regency, Lampung Province. Manifestation in research area is hot water pool with surface temperatures reach $90^{\circ} \mathrm{C}$. Data acquisition has been done by Wenner-Schlumberger configuration with 5 acquisition line. Line 1, line 4 and line 5 have 280 meters length. Line 2 have 240 meters length and line 3 have 320 meters length with a spacing of each electrodes in each lines is every 5 meters. The objective of this research are (1)examining the geochemical contaminant and fluid types, (2)identifies the geothermal fluid based on 2D and 3D resistivity data analysis, also (3)identifies the layer of rock in Padok manifestation area based on 2D and 3D subsurface resistivity section. Subsurface lithology in research area generally divides into 4 parts. Which is hot water fluid with mean resistivity value between $1 \Omega \mathrm{m}$ into $3 \Omega \mathrm{m}$ and based on geochemistry data the fluid type is chloride water; surface sediment with resistivity value between $6 \Omega \mathrm{m}$ into $50 \Omega \mathrm{m}$ and identified as swamp sediment and alluvium sediment divides into gravels, pebbles, sands, clay and peat; Gravels, pebbles, sands, clay and peat with resistivity value between $50 \Omega \mathrm{m}$ into $100 \Omega \mathrm{m}$; and igneous rock (andesite-basalt) with resistivity value more than $100 \Omega \mathrm{m}$.
\end{abstract}

Keywords: Geoelectric, Hot Water Fluid, Padok manifestation, Resistivity, Wenner-Schlumberger

How to cite this article:

Pratama, W., dan Rustadi. 2019. Aplikasi Metode Geolistrik Resistivitas Konfigurasi Wenner-

Schlumberger Untuk Mengidentifikasi Litologi Batuan Bawah Permukaan Dan Fluida Panas Bumi Way Ratai Di Area Manifestasi Padok Di Kecamatan Padang Cermin Kabupaten Pesawaran Provinsi Lampung. Jurnal Geofisika Eksplorasi, 5 (1) p.30-44. doi: 10.23960/jge.v5i1.21 


\section{PENDAHULUAN}

Indonesia adalah negara yang memiliki sumber daya panas bumi terbesar di dunia. Potensi panas bumi yang terkandung di Indonesia mencapai 40 persen dari total cadangan panas bumi dunia. Jumlah sebanyak itu sebagian besar berada di Sumatera, Jawa dan Sulawesi (Saptadji, 2009).

Panas bumi Way Ratai memiliki banyak daerah manifestasi diantaranya manifesasi Padok terletak di Kecamatan Padang Cermin Kabupaten Pesawaran Provinsi Lampung. Survei pendahuluan yang telah dilakukan ditemukan beberapa manifestasi kolam air panas yang memiliki temperatur tinggi mencapai $90^{\circ} \mathrm{C}$.

Metoda resistivitas digunakan untuk mempelajari keadaan bawah permukaan dengan cara mempelajari sifat aliran listrik di dalam batuan di bawah permukaan bumi (Santoso, 2002). Metoda resistivitas dalam eksplorasi panas bumi telah digunakan dalam beberapa penelitian, diantaranya dilakukan oleh Widodo dkk (2005), Rakhmanto dkk, (2011), Widodo dan Mustang (2009) dan Haerudin dkk (2009).

Penelitian geolistrik dalam eksplorasi panas bumi menghasilkan nilai resistivitas berbeda untuk batuan penutup dan batuan reservoar. Pemahaman terhadap geologi lokal daerah penelitian dapat membantu interpretasi data geolistrik.

Tujuan dari dilakukannya penelitian ini adalah meneliti kandungan geokimia dan jenis fluida manifestasi padok, mengidentifikasi fluida panas bumi berdasarkan analisis data resistivitas 2D dan 3D di area manifestasi Padok, mengidentifikasi lapisan batuan di wilayah panas bumi Way Ratai area manifestasi Padok berdasarkan penampang bawah permukaan resisistivitas 2D dan 3D.

\section{TINJAUAN PUSTAKA}

\subsection{Daerah Penelitian}

Daerah penelitian terletak di Desa Padang Cermin Kecamatan Padang Cermin Kabupaten Pesawaran Propinsi Lampung, di paparkan pada Gambar 1. Gambar adanya manifestasi di daerah penelitian diperlihatkan pada Gambar 2 terletak pada kordinat UTM X 515280, UTM Y 9383175 dengan temperatur 900C dan UTM 515195, UTM Y 9383291 dengan Temperatur $85^{\circ} \mathrm{C}$.

Keberadaan panas bumi di daerah penelitian berdasarkan peta geologi Lembar Tanjung Karang terletak di sebelah tenggara Gunung Ratai dan sebelah selatan sesar Menanga. Batuan yang tersingkap di daerah penelitian yang ditunjukkan oleh kotak berwarna merah Gambar 3 didominasi oleh batuan gunung api muda diantaranya adalah batu lava (andesit-basal), breksi dan tuf, dan batuan endapan permukaan diantaranya adalah endapan rawa, dan endapan aluvium.

Berdasarkan peta geologi Lembar Tanjungkarang, menjelaskan mengenai urutan stratigrafi daerah penelitian yaitu: yaitu batuan tertua berada pada zaman paleozoikum (paleozoic) dan jenisnya yaitu batuan malihan (metamorphic rocks) diantaranya adalah batuan sekis pelitan dan sedikit gnes, juga mencakup kuarsit dengan sisipan sekis-kuarsa serisit dan batu pualam, sekis amfibol hijau, amfibol orthogenes dioritan, campuran granitoid dan sekis atau gnes dan diterobos oleh urat granit pegmatit dari Gunung Kasih (Pzg). Batuan termuda yaitu berada pada zaman holosen (holocene) dengan memiliki 2 variasi jenis batuannya yaitu batuan gunung api muda; diantaranya adalah batu lava (andesit-basal), breksi dan tuf, dan batuan endapan permukaan, diantaranya adalah endapan rawa, dan endapan alluvium. 


\subsection{Sistem Panas Bumi}

Sistem panas bumi tersusun oleh batuan penudung, reservoir, sumber panas dan daerah resapan Gambar 4. Air hujan (rain water) akan merembes ke dalam tanah melalui saluran pori-pori atau ronggarongga diantara butir-butir batuan, sehingga air dengan leluasa menerobos turun ke batuan panas (hot rock). Air tersebut terakumulasi dan terpanaskan oleh batuan panas (hot rock), akibatnya suhu air meningkat. Tekanan yang terus meningkat menyebabkan air panas naik ke atas melalui celah, retakan dan pori-pori (Suharno, 2010).

Keberadaan suatu sistem panas bumi biasanya dicirikan oleh adanya manifestasi di permukaan, yaitu berupa:

1. Mata air panas (hot spring)

Batuan dalam dapur magma dapat menyimpan panas sampai ribuan tahun. Air tanah yang turun dan bersentuhan dengan magma akan terpanaskan dan cenderung naik ke permukaan melalui rekahan-rekahan pada batuan dan membentuk sumber mata air panas.

\section{Fumarola dan solfatara}

Merupakan lubang asap tempat dikeluarkannya gas-gas yang dihasilkan oleh gunung api. Sedangkan solfatara merupakan fumarola yang mengeluarkan gas belerang (sulfur), seperti $\mathrm{SO}_{2}, \mathrm{H}_{2} \mathrm{~S}$, dan $\mathrm{S}$.

\section{Geyser}

Adalah air tanah yang tersembur keluar sebagai kolam uap dan air panas, terbentuk oleh adanya celah yang terisi air dari kawah. 4. Uap Tanah (Steaming Ground)

Di beberapa daerah lapangan panas bumi sering ditemukan tempat-tempat yangmengeluarkan uap panas (steam) nampak keluar dari permukaan tanah. Manifestasi seperti ini biasa disebut uap tanah (steaming ground).

\section{Lumpur panas}

Merupakan manifestasi panasbumi di permukaan, umumnnya mengandung uap panas yang tidak terlalu banyak dan gas
$\mathrm{CO}_{2}$ yang tidak mudah menjadi cair (mengembun).

6. Kawah (crater)

Puncak atau daerah sekitar puncak gunung api terdapat kawah, yaitu suatu bentuk depresi berbentuk corong terbuka ke atas yang merupakan tempat disemburkannya tepra gas-gas, lava dan gasgas.

7. Batuan Alterasi

Batuan alterasi terjadi karena proses interaksi antara batuan asal dengan fluida panas bumi. Batuan alterasi terjadi karena beberapa faktor, antara lain suhu, tekanan, jenis batuan, komposisi fuida, $\mathrm{pH}$ dan lamanya interaksi (Suharno, 2010).

\subsection{Data Geokima}

Analisis geokimia perlu dilakukan untuk mengetahui karakteristik dan jenis dari daerah panas bumi. Geokimia panas bumi biasanya berisikan komposisi unsur, $\mathrm{pH}$ dan suhu. Jenis jenis fluida berdasarkan kandungan kimia:
a. Air Sulfat $\left(\mathrm{SO}_{4}\right)$
b. Air Klorida $(\mathrm{Cl})$
c. Air Bikarbonat $\left(\mathrm{HCO}_{3}\right)$

\subsection{Hubungan Resistivitas Dengan Akuifer}

Hubungan antara nilai resistivitas dengan jenis batuan dapat dipengaruhi oleh beberapa faktor antara lain :

1. Batuan sedimen yang lepas akan mempunyai nilai resistivitas yang lebih rendah dibandingkan dengan batuan sedimen kompak.

2. Kesarangan/porositas batuan. Batuan yang porous mempunyai nilai resistivitas lebih rendah dari pada batuan yang tidak porous.

3. $\mathrm{pH}$ dari air dalam rongga batuan. $\mathrm{pH}$ rendah menunjukkan batuan yang asam dengan nilai resistivitas rendah.

4. Resistivitas batuan akan bervariasi dari satu tempat ke tempat lain dan tergantung pada lingkungan pengendapan setempat. 
5. Resistivitas dapat berbeda secara mencolok, tidak saja dari satu lapisan kelapisan yang lain tetapi dalam satu lapisan batuan.

6. Temperatur air tinggi (air panas) mempunyai nilai reistivitas rendah dibandingkan dengan temperatur air lebih rendah (segar).

7. Permeabilitas atau keasanggupan suatu batuan yang mempunyai pori-pori untuk mengalirkan cairan.

8. Kesarangan (porositas) batuan adalah perbandingan antara volume rongga dengan volume batuan seluruhnya $\mathrm{Vr} / \mathrm{V}$ x $100 \%$, kesarangan besar berarti volume air yang tersimpan besar (Daulay, 2017).

\subsection{Penelitian Panas Bumi Terdahulu Menggunakan Metode Geolistrik}

Metoda resistivitas dalam eksplorasi panas bumi telah digunakan dalam beberapa penelitian. Metode resistivitas dalam eksplorasi panas bumi diantaranya dilakukan oleh Minarto (2011) di daerah panas bumi Mataloko menggunakan metoda geolistrik konfigurasi Schlumberger menunjukkan bahwa terdapat lapisan yang bersifat konduktif dengan resistivitas $<5$ $\Omega \mathrm{m}$ diperkirakan sebagai lapisan penudung dan lapisan yang bersifat agak resistif (10 $\Omega \mathrm{m}-100 \Omega \mathrm{m})$ diperkirakan sebagai reservoir dari sumber panas bumi daerah Mataloko.

Apostolopoulos (2005) dapat memberikan informasi bawah permukaan pada daerah Sperchios River Valley, Central Greece. Suhendra (2008) ) melakukan penelitian di daerah prospek panas bumi Air Kopras, Bengkulu. Nilai tahanan jenis bawah permukaan yang dapat diinterpretasikan sebagai sumber panas bumi berkisar antara $0,00308 \Omega \mathrm{m} \mathrm{Wm}-$ 3,55 $\Omega \mathrm{m}$.

Daerah panas bumi Suwawa, berdasarkan penelitian Widodo dkk, (2005) memiliki lapisan yang diduga sebagai lapisan penutup dengan kedalaman puncak lapisan antara $200-800 \mathrm{~m}$ dan tebal $150-$
$350 \mathrm{~m}$. Prospek panas bumi daerah panas bumi Suwawa berada di sekitar mata air panas Libungo seluas $\geq 7 \mathrm{~km}^{2}$.

Rakhmanto dkk, (2011) memberikan nilai resistivitas rendah $(<15 \Omega \mathrm{m}$ dan 15 sampai $<40 \Omega \mathrm{m}$ ) untuk batuan penutup dan resistivitas sedang (40 sampai $<200 \Omega \mathrm{m}$ ) untuk reservoar. Haeruddin dkk, (2009) memberikan nilai resistivitas $\leq 35 \Omega \mathrm{m}$ untuk reservoar dan $<10 \Omega$ m untuk batuan penutup.

Widodo dan Mustang (2009) memberikan nilai resistivitas rendah sampai sedang (25 - $40 \Omega \mathrm{m}$ ) untuk batuan penutup dan resistivitas tinggi ( $>90 \Omega \mathrm{m}$ ) untuk reservoar.

\section{TEORI DASAR}

\subsection{Prinsip Dasar Kelistrikan Bumi}

Metode geolistrik tahanan jenis merupakan salah satu alternatif yang digunakan untuk ekplorasi dangkal. Metode ini memanfaatkan kontras sifat resistivitas (tahanan jenis) dari lapisan batuan di dalam bumi sebagai media/alat untuk mempelajari keadaan geologi bawah permukaan.

Aliran arus listrik di dalam batuan/mineral dapat digolongkan menjadi 3 macam yaitu :

1. Konduksi elektronik

Konduksi ini adalah tipe normal dari aliran arus listrik dalam batuan/mineral.

2. Konduksi elektrolitik

Konduksi jenis ini banyak terjadi pada batuan/mineral yang bersifat porus dan pada pori-pori tersebut terisi oleh larutan elektrolit.

3. Konduksi dielektrik

Konduksi ini terjadi pada batuan yang bersifat dielektrik artinya batuan tersebut mempunyai elektron bebas sedikit bahkan tidak ada sama sekali (Hendrajaya dan Arif, 1990).

\subsection{Potensial Listrik Pada Bumi}

Potensial listrik alam atau potensial diri disebabkan karena terjadinya kegiatan 
elektrokimia mekanik. Faktor pengontrol dari semua kejadian ini adalah air tanah. Potensial alam ini dapat dikelompokkan menjadi 4 yaitu :

1. Potensial elektrokinetik

Potensial ini disebabkan bila suatu larutan bergerak melalui suatu pipa kapiler atau medium yang berpori

2. Potensial diffusi

Potensial ini disebabkan bila terjadi perbedaan mobilitas dari ion dalam larutan yang mempunyai konsentrasi berbeda.

3. Potensial Nerust

Potensial ini timbul bila suatu elektroda dimasukkan ke dalam larutan homogen.

4. Potensial mineralisasi

Potensial ini timbul bila dua elektroda logam dimasukkan kedalam larutan homogen.

\subsubsection{Dasar Perumusan Potensial Geolistrik Metode Resistivitas}

Bumi diasumsikan sebagai medium yang homogen isotropis diperlihatkan perjalanan arus yang kontinu pada medium bumi. Anggapan bumi sebagai medium homogen isotropis dimana bumi memiliki simetri bola, sehingga potensial merupakan fungsi jarak (r) saja. Maka persamaan potensial dalam bumi berbentuk:

$$
\begin{aligned}
& V=V_{(r)} \\
& \frac{d^{2} V_{(r)}}{d r^{2}}+\frac{2}{r} \frac{d V_{(r)}}{d r}=0 \\
& V_{(r)}=\frac{c_{1}}{r}+C_{2}
\end{aligned}
$$

dengan $\mathrm{C}_{1}$ dan $\mathrm{C}_{2}$ adalah konstanta sembarang. Untuk menentukan kedua konstanta tersebut diterapkan syarat batas yang harus dipenuhi potensial $\mathrm{V}(\mathrm{r})$ yaitu: untuk jarak $(\mathrm{r})$ tak terhingge $(r=\sim))$ atau jarak yang sangat jauh, $V_{(r \rightarrow \infty)}=0$ sehingga $\mathrm{C}_{2}=0$ dan persamaan (3.3) akan menjadi:

$$
V_{(r)}=\frac{c_{1}}{r}
$$

\subsubsection{Satu titik arus di permukaan}

Sumber arus listrik titik yang berada di permukaan bumi akan merambat ke segala arah secara radial berbentuk setengah permukaan bola. Persamaan potensial listrik dapat dirumuskan:

$V_{(r)}=\frac{I \rho}{2 \pi r}$

$\rho=2 \pi r \frac{V}{I}$

dengan adalah nilai resistivitas bahan/ benda dalam satuan ohm.m (Telford et al, 1976).

\subsubsection{Dua titik arus dipermukaan}

Dua elektroda untuk mengalirkan arus $C_{1}$ dan $C_{2}$ beda potensialnya diukur antara 2 titik dengan dua elektroda potensial $P_{1}$ dan $P_{2}$. Besarnya tahanan jenis semu adalah

$$
\begin{aligned}
& \rho_{a}=\frac{\Delta V}{I} 2 \pi\left(\frac{1}{r_{1}}-\frac{1}{r_{2}}-\frac{1}{r_{3}}+\frac{1}{r_{4}}\right)^{-1} \\
& K=2 \pi\left(\frac{1}{r_{1}}-\frac{1}{r_{2}}-\frac{1}{r_{3}}+\frac{1}{r_{4}}\right)^{-1}
\end{aligned}
$$

Dimana:

$\Delta \mathrm{V}=$ beda potensial antara $\mathrm{P}_{1}$ dan $\mathrm{P}_{2}$ (volt) $\mathrm{I}=$ besarnya arus yang dinjeksikan melalui elektroda $\mathrm{C}_{1}$ dan $\mathrm{C}_{2}$ (ampere).

$\mathrm{r}_{1}=$ jarak antara $\mathrm{C}_{1}$ dan $\mathrm{P}_{1}$ (meter)

$\mathrm{r}_{2}=$ jarak antara $\mathrm{C}_{2}$ dan $\mathrm{P}_{2}$ (meter)

$\mathrm{r}_{3}=$ jarak antara $\mathrm{C}_{1}$ dan $\mathrm{P}_{2}$ (meter)

$\mathrm{r}_{4}=$ jarak antara $\mathrm{C}_{2}$ dan $\mathrm{P}_{2}$ (meter)

$\mathrm{K}=$ faktor geometri yang berdimensi panjang (meter).

(Hendrajaya dan Arif, 1990).

\subsection{Konfigurasi Wenner-Schlumberger}

Faktor geometri konfigurasi WennerSchlumberger diperoleh dari menyubstitusikan nilai jarak spasi elektroda pada Gambar 5 kepersamaan 3.7, sehingga diperolah faktor geometrik $\mathrm{K}$ sebagai berikut :

$$
K=\pi n(n+1) a
$$

(Hendrajaya dan Arif, 1990). 
satu konfigurasi paling umum digunakan untuk survei resistivitas 2D. Kedalaman rata-rata pada konfigurasi ini $10 \%$ lebih besar dari konfigurasi Wenner (Telford et al, 1990).

\subsection{Pemodelan 2D Res2Dinv}

Penampang 2D merupakan penampang untuk menggambarkan hasil survei secara 2D dengan metode conturing pseudosection. Pseudosection dihasilkan dari proses pemodelan forward maupun inversi, sehingga diperoleh nilai resistivitas yang sudah terkoreksi (topographic effect). Res2Dinv adalah program komputer yang secara outomatis menentukan model resistivitas 2 dimensi (2D) untuk bawah permukaan dari data hasil survei geolistrik. Program ini dapat digunakan untuk survei menggunakan konfigurasi Wenner, polepole, dipole-dipole, pole-dipole, Schlumberger, Wenner- Schlumberger dan array dipole-dipole ekuator.

Hasil inversi merupakan distribusi nilai resistivitas material bawah permukaan Bumi yang disebut Resistivity pseudosection atau inverse model resistivity section. Model yang diperoleh melalui proses inverse akan selalu memiliki nilai Residual Error atau Root Mean Squared Error (RMSE) (Loke, 1999).

\section{METODOLOGI PENELITIAN}

\subsection{Waktu dan Tempat}

Penelitian ini yang telah dilakukan pada bulan mei 2016, di daerah panas bumi Way Ratai area manifestasi Padok Desa Padang Cermin Kecamatan Padang Cermin Kabupaten Pesawaran Provinsi Lampung.

\subsection{Alat dan bahan}

Alat-alat yang digunakan dalam penelitian ini sebagai berikut:

- ARES resistivity IP meter

- Elektroda 64 buah

- Kabel multi-channel 8 gulungan

- Aki 12 volt
- GPS (Global Positioning System) Maps 76Csx

- Palu

- Handy Talky (HT)

- Meteran

- Laptop

\subsection{Data Pendukung}

a. Peta geologi lembar tanjung karang

b. Peta citra penelitian dari Google Earth

\subsection{Desain Pengukuran}

Pengukuran menggunakan aplikasi metode geolistrik tahanan jenis dengan konfigurasi Wenner-schlumberger pada Gambar 6 di area penelitian terdiri dari 5 lintasan pengukuran. Lintasan 1 memiliki panjang lintasan $280 \mathrm{~m}$, lintasan 2 memiliki panjang lintasan 240 meter, lintasan 3 memiliki panjang lintasan 320 meter, lintasan 4 memiliki panjang lintasan 280 meter dan lintasan 5 memiliki panjang lintasan 280 meter dengan spasi elektroda setiap lintasan pengukuran yaitu 5 meter.

\subsection{Pengolahan Data}

\subsubsection{Pengolahan data 2D}

Hasil pengukuran yang didapatkan dari lapangan berupa data resistivitas yang tersimpan otomatis pada alat Ares Resisty IP meter kemudian dilakukan pemindahan dari alat dalam bentuk file "dat" ke laptop setelah itu diolah dengan menggunakan perangkat lunak Res2Dinv. Langkahlangkah penggunaan Res2Dinv adalah sebagai berikut:

1. Mengolah data pengukuran dari alat menggunakan program Excel untuk melihat nama lintasan, resistivitas semu, jumlah titik datum dan lain- lain setelah itu menambahkan data topograpi dan kordinat pengukuran yang sudah didapatkan dengan GPS. Menyimpan data tersebut pada text editor.

2. Mengolah data tersebut menggunakan software Res2Dinv, pengolahan data dilakukan untuk mendapatkan 
penampang resistivitas 2D dengan topografi sesuai pada Gambar 7.

\subsubsection{Pengolahan Data 3D Resistivitas}

Data resistivitas yang telah diinversi selanjutnya dipilih untuk dilakukan pengolahan $3 \mathrm{D}$, dalam penelitian ini penulis memilih data iterasi 5 dari setiap lintasan pengukuran yang selanjutnya akan diolah menggunakan software 3D geofisika. Software yang digunakan yaitu Voxler versi 4.

Sebelum pengolahan dilakukan pembuatan data input dan menggabungkan data iterasi 5 setiap lintasan dalam Microsoft Excel yang terdiri dari kolom X (lokasi-X), Y (lokasi-Y), $\mathrm{Z}$ (lokasi Z/kedalaman) dalam bentuk UTM yang didapatkan dari GPS di lokasi penelitian, resistivity iterasi 5 dan kolom id.

Pada tahap pengolahan hal yang perlu dilakukan yaitu menampilkan sumbu XYZ, menampilkan kotak batas yang digunakan sebagai pembatas pemodelan, menampilkan scatter plot yang berguna untuk memunculkan titik-titik data pada jendela utama, kemudian dilakukan proses gridding seperti Gambar 8.

\subsection{Interpretasi Data}

Interpretasi dilakukan dengan mengkorelasikan hasil pengolahan data software yang berupa informasi (nilai resistivitas, kedalaman, ketebalan) dengan pengetahuan dasar aspek-aspek tahanan jenis batuan seperti yang ditulis di atas, informasi geologi, informasi kondisi sumur penduduk (kedalaman dan rasa) sekitar, pengetahuan hidrogeologi, mengacu tabel resistivitas batuan yang terdapat pada Tabel 1. (Telford et al, 1990) dan referensi terkait penelitian panas bumi mengunakan metode geolistrik yang telah dilakukan terdahulu sehingga diperoleh gambaran informasi struktur batuan yang sebenarnya.

\section{HASIL DAN PEMBAHASAN}

\subsection{Hasil Penelitian}

\subsubsection{Penelitian Geokimia}

Dari hasil penelitian geokimia di manifestasi Padok diperlihatkan pada Tabel 2.

\subsubsection{Penampang Resistivitas}

Penampang dan nilai resistivitas 2D lintasan 1 sampai lintasan 5 diperlihatkan Gambar 9 sampai dengan 13. Posisi lintasan pengukuran di dalam model 3D pada Gambar 14, sebaran fluida air panas berdasarkan penampang resistivitas 3D pada Gambar 15 dan pemotongan model resistivitas 3D pada Gambar 16.

\subsection{Pembahasan}

\subsubsection{Lintasan 1}

Nilai resistivitas pada lintasan ini bervariasi dari 1,1 $\Omega \mathrm{m}$ hingga $146 \Omega \mathrm{m}$ dengan kedalaman penetrasi kurang lebih 45 meter dan tingkat error data 17,3\%. Berdasarkan peta geologi daerah penelitian dan tabel nilai resistivitas serta data geokimia maka dapat diidentifikasi litologi yang terdapat di daerah penelitaian dengan nilai resistivitas $1,1 \Omega \mathrm{m}$ sampai dengan 2,3 $\Omega \mathrm{m}$ ditunjukan warna biru merupakan fluida air panas dikarenakan temperatur air tinggi (air panas) mempunyai nilai resistivitas rendah dibandingkan dengan temperatur air lebih rendah.

Fluida didaerah penelitian ini mengandung unsur $\mathrm{Na}$ dan $\mathrm{Cl}$ tinggi, semakin tinggi kandungan kedua unsur tersebut di dalam fluida maka nilai resistivitas terukur semakin rendah.

Berdasarkan anion $\mathrm{Cl}, \mathrm{SO}_{4}$ dan $\mathrm{HCO}_{3}$ pada Tabel 2 tipe air panas yang terdapat di daerah penelitian adalah air klorida.

Kadar Mg yang lebih tinggi yaitu 57,9 persen dibandingkan dengan kadar K 21,1 persen dan $\mathrm{Na} 21$ persen dapat disimpulkan 
bahwa fluida panas di daerah penelitian telah mengalami proses pencampuran dengan air tanah dan batuan permukaan dan mengindikasikan bahwa manifestasi air panas tersebut berada pada zona autflow.

Kandungan $\mathrm{Na}$ yang cukup tinggi yaitu $1197 \mathrm{ml} / \mathrm{l}$ mengindikasikan air fluida di daerah penelitian kemungkinan besar bercampur dengan intrusi air laut.

Nilai resistivitas 4,6 $\Omega \mathrm{m}$ sampai dengan 36,5 $\Omega \mathrm{m}$ ditunjukan warna hijau sampai kuning diidentifikasikan litologi endapan permukaan diantaranya adalah endapan rawa, dan endapan alluvium terdiri dari kerakal, kerikil, pasir, lempung, dan gambut. Nilai resistivitas $36,5 \Omega \mathrm{m}$ sampai dengan $72,9 \Omega \mathrm{m}$ diidentifikasikan litologi kerakal, kerikil, pasir, lempung. Nilai resistivitas $146 \Omega \mathrm{m}$ ditunjukan warna merah sampai dengan ungu diidentifikasikan batuan lava (andesit-basal) dalam kondisi basah.

\subsubsection{Lintasan 2}

Nilai resistivitas pada lintasan ini bervariasi dari 1,5 $\Omega \mathrm{m}$ hingga $198 \Omega \mathrm{m}$ dengan kedalaman penetrasi kurang lebih 45 meter dan tingkat error data $10,7 \%$. Nilai resistivitas $1,5 \Omega \mathrm{m}$ sampai dengan 3,1 ditunjukan warna biru tua merupakan fluida air panas dikarenakan temperatur air tinggi (air panas). Untuk kandungan nilai $\mathrm{Cl}, \mathrm{B}, \mathrm{Li}$, $\mathrm{Mg}, \mathrm{K}$ dan $\mathrm{Na}$ sama seperti lintasan 1.

Kandungan $\mathrm{Na}$ yang cukup tinggi yaitu $1197 \mathrm{ml} / \mathrm{l}$ mengindikasikan air fluida di daerah penelitian kemungkinan besar bercampur dengan intrusi air laut. Nilai resistivitas $6,2 \Omega \mathrm{m}$ sampai dengan $49.6 \Omega \mathrm{m}$ ditunjukan warna hijau sampai kuning diidentifikasikan berupa litologi endapan rawa, dan endapan alluvium terdiri dari kerakal, kerikil, pasir, lempung, dan gambut. Nilai resistivitas 49,6 $\Omega \mathrm{m}$ sampai dengan 99,2 $\Omega \mathrm{m}$ ditunjukan kuning sampai kuning genteng diidentifikasikan litologi kerakal, kerikil, pasir dan lempung. Nilai resistivitas $198 \Omega$ m ditunjukan warna merah sampai dengan ungu diidentifikasikan batuan lava (andesit-basal).

\subsubsection{Lintasan 3}

Nilai resistivitas pada lintasan ini bervariasi dari 1,5 $\Omega \mathrm{m}$ hingga $197 \Omega \mathrm{m}$ dengan kedalaman penetrasi kurang lebih 59,9 meter dan tingkat error data 15,9\%. Untuk kandungan nilai $\mathrm{Cl}, \mathrm{B}, \mathrm{Li}, \mathrm{Mg}, \mathrm{K}$ dan $\mathrm{Na}$ sama seperti lintasan 2. Nilai resistivitas 6,2 $\Omega \mathrm{m}$ sampai dengan 49,3 $\Omega \mathrm{m}$ ditunjukan warna hijau sampai kuning diidentifikasikan litologi endapan permukaan diantaranya adalah endapan rawa, dan endapan alluvium terdiri dari kerakal, kerikil, pasir, lempung, dan gambut terdapat. Nilai resistivitas $49,3 \Omega \mathrm{m}$ sampai dengan 98,6 $\Omega \mathrm{m}$ ditunjukan warna kuning sampai dengan kuning genteng diidentifikasikan litologi kerakal, kerikil, pasir dan lempung. Nilai resistivitas 197 $\Omega \mathrm{m}$ ditunjukan warna merah sampai dengan ungu diidentifikasikan batuan lava (andesitbasal).

\subsubsection{Lintasan 4}

Nilai resistivitas pada lintasan ini bervariasi dari 1,9 $\Omega \mathrm{m}$ hingga $247 \Omega \mathrm{m}$ dengan kedalaman penetrasi kurang lebih 52 meter dan tingkat error data $17,4 \%$. Nilai resistivitas $1,9 \Omega \mathrm{m}$ sampai dengan $3,9 \Omega \mathrm{m}$ ditunjukan warna biru tua merupakan fluida air panas dikarenakan temperatur air tinggi (air panas). Untuk kandungan nilai $\mathrm{Cl}, \mathrm{B}, \mathrm{Li}$, $\mathrm{Mg}$, $\mathrm{K}$ dan $\mathrm{Na}$ sama seperti lintasan sebelumnya.

Nilai resistivitas $7,7 \Omega \mathrm{m}$ sampai dengan $61,8 \Omega \mathrm{m}$ ditunjukan warna hijau sampai kuning diidentifikasikan litologi endapan permukaan diantaranya adalah endapan rawa, dan endapan alluvium terdiri dari kerakal, kerikil, pasir, lempung, dan gambut terdapat. Nilai resistivitas $61,8 \Omega \mathrm{m}$ sampai dengan $124 \Omega \mathrm{m}$ ditunjukan warna kuning sampai dengan kuning genteng diidentifikasikan litologi kerakal, kerikil, pasir dan lempung. Nilai resistivitas 197 $\Omega m$ ditunjukan warna merah sampai dengan ungu diidentifikasikan batuan lava (andesitbasal) dalam kondisi basah. 


\subsubsection{Lintasan 4}

Nilai resistivitas pada lintasan ini bervariasi dari $1 \Omega \mathrm{m}$ hingga $131 \Omega \mathrm{m}$ dengan kedalaman penetrasi kurang lebih 52 meter dan tingkat error data 15,9 \%. Berdasarkan peta geologi daerah penelitian dan tabel nilai resistivitas serta didukung data geokimia maka dapat diidentifikasi litologi yang terdapat di daerah penelitaian dengan nilai resistivitas $1 \Omega \mathrm{m}$ sampai 2,1 $\Omega \mathrm{m}$ ditunjukan warna biru merupakan fluida air panas dikarenakan temperatur air tinggi (air panas). Untuk kandungan nilai $\mathrm{Cl}, \mathrm{B}, \mathrm{Li}$, $\mathrm{Mg}, \mathrm{K}$ dan $\mathrm{Na}$ sama seperti lintasan sebelumnya.

Nilai resistivitas $4,2 \Omega \mathrm{m}$ sampai dengan $32,8 \Omega \mathrm{m}$ ditunjukan warna hijau sampai kuning diidentifikasikan dengan litologi endapan permukaan diantaranya adalah endapan rawa, dan endapan alluvium terdiri dari kerakal, kerikil, pasir, lempung, dan gambut terdapat. Nilai resistivitas $32,8 \Omega \mathrm{m}$ sampai dengan $65,6 \Omega \mathrm{m}$ ditunjukan warna kuning sampai dengan kuning genteng diidentifikasikan litologi kerakal, kerikil, pasir dan lempung. Nilai resistivitas 131 $\Omega \mathrm{m}$ ditunjukan warna merah sampai dengan ungu diidentifikasikan batuan lava (andesitbasal) dalam kondisi basah.

\subsubsection{Model 3D daerah penelitian}

Data2D yang telah dilakukan inversi selanjutnya diekstrak kemudian digabungkan menjadi 3D menggunakan software geofisika diperlihatkan pada Gambar 14. Garis dengan warna merah, hijau dan biru merupakan variable $\mathrm{X}, \mathrm{Ydan}$ $\mathrm{Z}$ lokasi penelitian, dimana $\mathrm{X}$ merupakan kordinat UTM X, Y merupakan UTM Y dan $\mathrm{Z}$ merupakan elevasi atau kedalaman berguna untuk mempermudah pengamatan lokasi penelitian. Titik berwarna hitam menggambarkan posisi lintasan pengukuran di dalam model 3D dan garis pada bagian atas model 3D ditunjukan dengan warna hijau (rendah) sampai dengan merah (tinggi) merupakan kondisi topografi lokasi penelitian.Sebaran fluida air panas diperlihatkan Gambar 15. ditunjukan oleh warna biru pada penampang tersebut.

Untuk mempermudah dalam melakukan interpretasi litologi bawah permukaan daerah penelitian ini maka dilakukan pembagian area interpretasi di dalam model 3D menjadi beberapa bagian diperlihatkan pada Gambar 16.

Model resistivitas 3D pertama ditunjukan Gambar 16 (a) pada UTM 9383200. Warna biru pada penampang ini memiliki rentang nilai resistivitas $1 \Omega \mathrm{m}$ sampai dengan $25 \Omega \mathrm{m}$ di identifikasi sebagai fluida air panas dikarenakan temperatur air tinggi (air panas) mempunyai nilai resistivitas rendah dibandingkan dengan temperatur air lebih rendah (segar) dan endapan rawa, serta endapan alluvium terdiri dari kerakal, kerikil, pasir, lempung, dan gambut. Warna kuning memiliki nilai resistivitas lebih besar dibandingkan warna biru dengan nilai resistivitas $49 \Omega \mathrm{m}$ sampai dengan $85 \Omega \mathrm{m}$ diidentifikasikan batuan dengan litologi kerakal, kerikil, pasir dan lempung.

Model resistivitas 3D kedua ditunjukan Gambar 16 (b) pada UTM 9383300. Warna biru pada model ini memiliki rentang nilai 1 $\Omega \mathrm{m}$ sampai dengan $25 \Omega \mathrm{m}$ di identifikasi sebagai fluida air panas dikarenakan temperatur air tinggi (air panas) mempunyai nilai resistivitas rendah dibandingkan dengan temperatur air lebih rendah (segar) dan endapan rawa, serta endapan alluvium terdiri dari kerakal, kerikil, pasir, lempung, dan gambut. Warna kuning memiliki nilai resistivitas lebih besar dibandingkan warna biru dengan nilai resistivitas $49 \Omega \mathrm{m}$ sampai dengan $85 \Omega \mathrm{m}$ diidentifikasi sebagai batuan kerakal, kerikil, pasir dan lempung. Warna merah memiliki nilai $88 \Omega$ m sampai dengan $205 \Omega \mathrm{m}$ diidentifikasikan batuan lava (andesit-basal) dalam kondisi basah sehingga nilai resistivitasnya kecil.

Model resistivitas 3D ketiga ditunjukan Gambar 16 (c) pada UTM 9383400. Model resistivitas sebelumnya pada Gambar 16 diperlihatkan tanda panah berwarna biru kemungkinan besar adalah arah dari sesar 
yang dilewati oleh fluida air panas klorida yang bersumber dari reservoar gunung ratai diperkuat dengan keberadaan manifestasi yang memanjang ke arah barat daya gunung ratai.

\section{KESIMPULAN DAN SARAN}

\subsection{Kesimpulan}

Kesimpulan pada penelitian ini sebagai berikut:

1. Data geokimia daerah penelitian menunjukan fluida air panas bersifat klorida yang bersumber dari reservoar gunung ratai akan tetapi dikarenakan fluida tersebut jauh dari daerah terbentuknya maka terkondensasi dengan air tanah dan batuan sekitarnya, diperkuat dengan beberapa unsur seperti nilai $\mathrm{Cl}$ lebih tinggi dibanding nilai $\mathrm{B}$ dan Li serta kadar Mg lebih tinggi dari $\mathrm{K}$ dan $\mathrm{Na}$.

2. Penampang 2D dan model resistivitas 3D menunjukan litologi batuan bawah permukaan secara umum dibagi menjadi 4 bagian yaitu fluida air panas memiliki nilai resistivitas rata-rata antara 1 $\Omega \mathrm{m}$ sampai dengan $3 \Omega \mathrm{m}$, memiliki nilai resistivitas $6 \Omega \mathrm{m}$ sampai dengan $50 \Omega \mathrm{m}$ dengan litologi endapan permukaan diantaranya adalah endapan rawa, dan endapan alluvium terdiri dari kerakal, kerikil, pasir, lempung, dan gambut, nilai resistivitas $50 \Omega \mathrm{m}$ sampai dengan $100 \Omega \mathrm{m}$ dengan litologi kerakal, kerikil, pasir dan lempung dan batuan lava (andesit-basalt) memiliki nilai resistivitas diatas $100 \Omega \mathrm{m}$.

3. Nilai resistivitas yang terukur di area penelitian tergolong rendah dikarenakan pada saat melakukan pengukuran dalam keadaan basah (musim penghujan) dan litologi berasosiasi dengan batuan lempung.

\subsection{Saran}

Saran yang perlu diberikan yaitu Perlu data pendukung seperti data pengeboran agar data resistivitas yang dihasilkan sesuai dengan keadaan bawah permukaan. Diperlukan survei geofisika lebih lanjut seperti metode gravity, magnetic dan magnetotelurik (MT) agar pola sesar (rekahan) yang dilewati fluida bisa terlihat.

\section{DAFTAR PUSTAKA}

Apostolopoulos, G. 2005. Geophysical Studies Relating to the Tectonic Structure, Geothermal Fields and Geomorphological Evolution of the Sperchios River Valley, Central Greece. Journal of Balkan Geophysical Society. 8: $99-112$.

Arnason, K. and Gislason, G, 2009, Geothermal Surface Exploration. Makalah disajikan dalam Short Course on Surface Exploration for Geothermal Resources, United Nations University Geothermal Training Programme and LaGeo, El Salvador 17 - 30 Oktober 2009.

Azwar, M., dkk, 1988, Pengantar Dasar Ilmu Gunungapi, Bandung: Penerbit Nova

Daulay, U.E., 2017. Geophysical reistivity test. Alamat situs: http://umared.blogspot.co.id/2011/02 /geophysical-resistivity-test.html, diakses pada tanggal 14 mei, pukul 09.00 .

Gupta, H. and Roy, S., 2007. Geothermal Energy: An Alternative Resource For the 21 st Century. Elsevier, Amsterdam.

Haerudin, N., Pardede, V.J. dan Rasimeng, S, 2009, Analisis Reservoar Daerah Potensi Panas Bumi Gunung Rajabasa Kalianda dengan Metode Tahanan Jenis dan Geotermometer, Jurnal Ilmu Dasar. 10:141 - 146.

Hendrajaya, L dan Arif, I. 1990, Geolistrik Tahanan Jenis, Laboratorium Fisika Bumi, Jurusan Fisika FMIPA ITB, Bandung. 
Loke, M.H, 2004, Tutorial $2 D$ and $3 D$ Electrical Imaging Surveys, Birmingham University, England.

Mangga, S.A., Amirudin., Suwarti, T., Gafoer, S. dan Sidarto. 1993. Peta Geologi Lembar Tanjung Karang, Sumatera, Pusat Penelitian dan Pengembangan Geologi, Bandung.

Meidav, T., 1972, Electrical resistivity in geothermal exploration, Presented paper in Annual Meeting, Society of Exploration Geophysicists 1972, Anaheim California.

Minarto, E. 201, Pemodelan Inversi Data Geolistrik untuk Menentukan Struktur Perlapisan Bawah Permukaan Daerah PanasBumi Mataloko, (personal.its.ac.id/files/pub/1692minarto-physics PENELITIAN_4, pdf diakses tanggal 20 mei2017).

Nurfalaq. Tutorial singkat voxler 3 dimensiberdasarkan data inversi resistivitas.

Https://www.academia.edu/2174591 4 diakses pada tanggal 1 febuari 2017.

Rakhmanto, F., Maryanto, S. dan Susilo A, 2011. ERT (Electrical Resistance Tomography) Sumber Air Panas Cangar Komplek Gunung Arjuno Welirang, Jurnal Neutrino, (Online), Vol. 4, No. 1, (ejournal.uinmalang.ac.id diakses 12 mei 2017).

Santoso, D, 2002, Pengantar Teknik Geofisika, Penerbit ITB, Bandung.

Saptadji, N.M., 2009. Karakteristik Reservoir Panas Bumi. ITB: Bandung

Soenarto, B., 2004, Pendugaan Geolistrik Lapangan di Bolok dan Sikumana, Kupang NTT. Buletin Pasair Vol XII., No.40
Suharno, 2010. Pengembangan Prospek Panas Bumi. Unila: Bandar Lampung.

Suhendra, 2008, Interpretasi Struktur Bawah Permukaan Daerah Prospek Panas Bumi di Desa Air Kopras Kab Lebong Berdasarkan Nilai Tahanan Jenis, Jurnal Gradien. 4: 300 - 303.

Telford, W.M., 1976, Geldart, L.P., Sheriff, R.E., and Keys, D.A., 1976, Applied Geophysics, Edisi 1,Cambridge University Press, Cambridge.

Widodo, S., dan Mustang, A. 2009, Potensi Panas Bumi Daerah Cubadak Berdasarkan Survei Geolistrik Schlumberger, Makalah disajikan dalam Kolokium Badan Geologi 2009, Pusat Sumber Daya Geologi Badan Geologi.

Widodo, S., Mustang, A., dan Zarkasyi, A, 2005, Penyelidikan Geolistrik dan Head On Daerah Panas Bumi Suwawa Kabupaten Bone Bolango

Provinsi Gorontalo. Makalah disajikan dalam Kolokium Badan Geologi 2005, Pusat Sumber Daya Geologi Badan Geologi.

Zohdy, A. A., Eaton, G. P., and Mabey, D.R., 1980, Application Of Surface Geophysics To Ground-Water Investigation, Chaptere D1, United States Govermant Printing Office, Washington. 


\section{LAMPIRAN}

Tabel 1. Nilai resistivitas batuan dan mineral (Telford, 1990).

\begin{tabular}{|c|c|}
\hline Rocks type & Resistivity range $(\mathrm{m})$ \\
\hline Granite porphyry & $4.5 \times 10^{3} \quad$ (wet)- \\
\hline Feldspar porphyry & $1.3 \times 10^{6} \quad(d r y)$ \\
\hline Syenite & $4 \times 10^{3}$ (wet) \\
\hline Diorite porphyry & $10^{2}-10^{6}$ \\
\hline Porphyryte & $1.9 \times 10^{3} \quad$ (wet) \\
\hline Carbonatized & $2.8 \times 10^{4} \quad(d r y)$ \\
\hline porphyry & $10-5 \times 10^{4}$ (wet)- \\
\hline Quartz diorite & $3.3 \times 10^{3} \quad(d r y)$ \\
\hline Porphyry (various) & $2.5 \times 10^{3} \quad$ (wet) - \\
\hline Dacite & $6 \times 10^{4}(d r y)$ \\
\hline Andesite & $2 \times 10^{4}-2 \times 10^{6}$ \\
\hline Diabase (various) & $(w e t)-1.8 \times 10^{5}$ \\
\hline Lavas & $(d r y)$ \\
\hline Gabbro & $60-10^{4}$ \\
\hline Basalt & $2 \times 10^{4}(w e t)$ \\
\hline Olivine norite & $4.5 \times 10^{4} \quad$ (wet)- \\
\hline Peridotite & $1.7 \times 10^{2} \quad(d r y)$ \\
\hline Hornfels & $20-5 \times 10^{7}$ \\
\hline Schists (calcareous & $10^{2}-5 \times 10^{4}$ \\
\hline and mica) & $10^{3}-10^{6}$ \\
\hline Tuffs & $10-1.7 \times 10^{7}(d r y)$ \\
\hline Graphite schists & $10^{3}-6 \times 10^{4}(w e t)$ \\
\hline Slate (various) & $3 \times 10^{3}$ (wet)- \\
\hline Gneiss (various) & $6.5 \times 10^{3} \quad(d r y)$ \\
\hline
\end{tabular}

\begin{tabular}{|l|l|} 
Marble & $8 \times 10^{3}($ wet $)-$ \\
Skarn & $6 \times 10^{7}($ dry $)$ \\
Quartzites (various) & $20-10^{4}$ \\
Consolidated shales & $2 \times 10^{3}($ wet $)-10^{5}$ \\
Argillites & $($ dry) \\
Conglomerates & $10-10^{2}$ \\
Sandstones & $6 \times 10^{2}-4 \times 10^{7}$ \\
Limestones & $6.8 \times 10^{4} \quad($ wet $)-$ \\
Dolomite & $3 \times 10^{6}($ dry $)$ \\
Unconsolidated wet & $10^{2}-2.5 \times 10^{8}($ dry) \\
clay & $2.5 \times 10^{2} \quad($ wet $)-$ \\
Marls & $2.5 \times 10^{8} \quad($ dry $)$ \\
Clays & $10-2 \times 10^{8}$ \\
Oil sands & $20-2 \times 10^{3}$ \\
Surface water & $10-8 \times 10^{2}$ \\
(ign.rock) & $2 \times 10^{3}-10^{4}$ \\
Surface water & $1-6.4 \times 10^{8}$ \\
(sediments) & $50-10^{7}$ \\
Soil waters & $3.5 \times 10^{2}-5 \times 10^{3}$ \\
\hline
\end{tabular}

Tabel 2. Data Geokimia daerah penelitian

\begin{tabular}{|c|c|c|c|c|c|c|c|c|c|c|}
\hline Unsur & Temp & $\mathrm{pH}$ & DHL & $\mathrm{Na}$ & $\mathrm{K}$ & $\mathrm{Li}$ & $\mathrm{C}_{2}$ & $\mathrm{Mg}$ & $\mathrm{Cl}$ & S04 \\
\hline Satuan & $\mathrm{C}$ & & umhos & $\mathrm{mgl}$ & $\mathrm{mgl}$ & $\mathrm{mgl}$ & $\mathrm{mgl}$ & $\mathrm{mgl}$ & $\mathrm{mgl}$ & $\mathrm{mgl}$ \\
\hline & 92 & 7,41 & 915 & 1197 & 120,6 & 15,9 & 47,3 & 10,9 & 1939,3 & 74,1 \\
\hline \multirow{3}{*}{$\begin{array}{l}\text { Unsur } \\
\text { Satuan }\end{array}$} & $\mathrm{HCO} 3$ & B & $\mathrm{SiO2}$ & \multicolumn{4}{|c|}{ Cl-SO4-HCO3 } & & & \\
\hline & $\mathrm{mgl}$ & mgl & $\mathrm{mgl}$ & S & $\% \mathrm{Cl}$ & $\begin{array}{l}\text { \%HCO } \\
3\end{array}$ & $\% \mathrm{SO4}$ & & & \\
\hline & 157,7 & 1,7 & 347,8 & 2171 & 89,3 & 7,3 & & & & \\
\hline Unsur & \multicolumn{4}{|c|}{ Cl-Li-B } & \multicolumn{4}{|c|}{$\mathrm{Na} \cdot \mathrm{K} \cdot \mathrm{Mg}$} & & \\
\hline \multirow[t]{2}{*}{ Satuan } & $\mathrm{S}$ & $\% \mathrm{Cl}$ & $\% B$ & $\% \mathrm{Li}$ & $\mathrm{S}$ & $\% \mathrm{Na}$ & $\% \mathrm{Mg}$ & $\% \mathrm{~K}$ & & \\
\hline & 35,8 & 54,2 & 1,2 & 44,6 & 5,7 & 21 & 57,9 & 21,1 & & \\
\hline
\end{tabular}

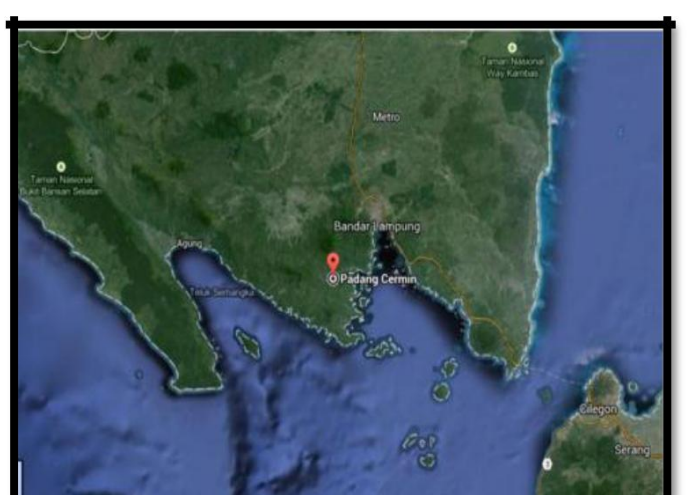

Gambar 1. Lokasi penelitian Google maps 2017 


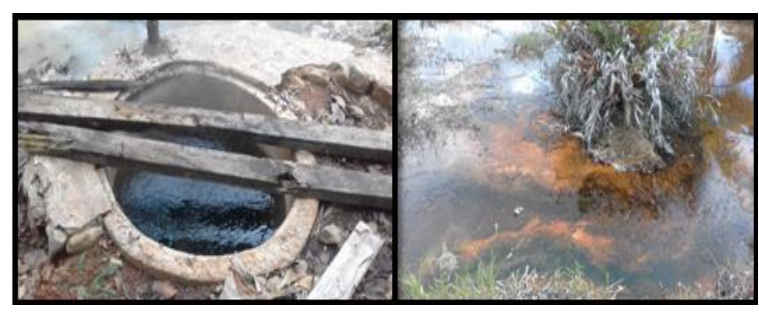

Gambar 2. Manifestasi daerah penelitian.

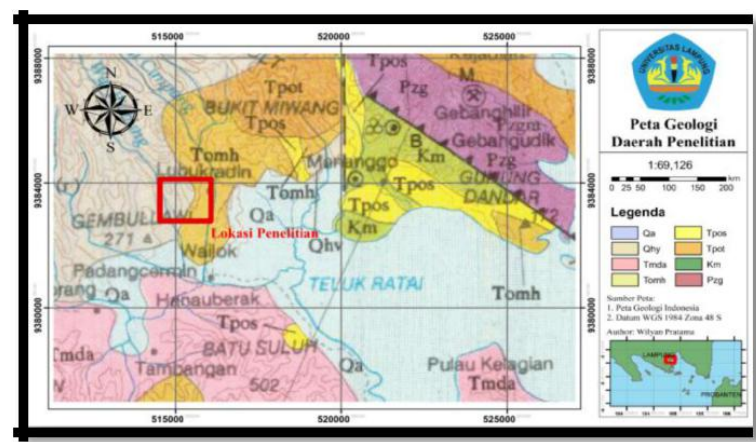

Gambar 3. Peta Geologi daerah penelitian (Mangga dkk, 1993)

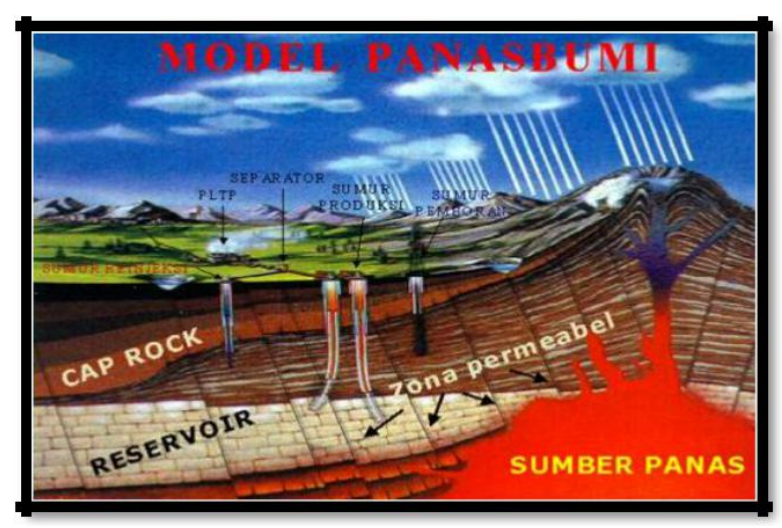

Gambar 4. Model sistem panas bumi lapangan Ulubelu, Kabupaten Tanggamus, Lampung (PGE, 2008).

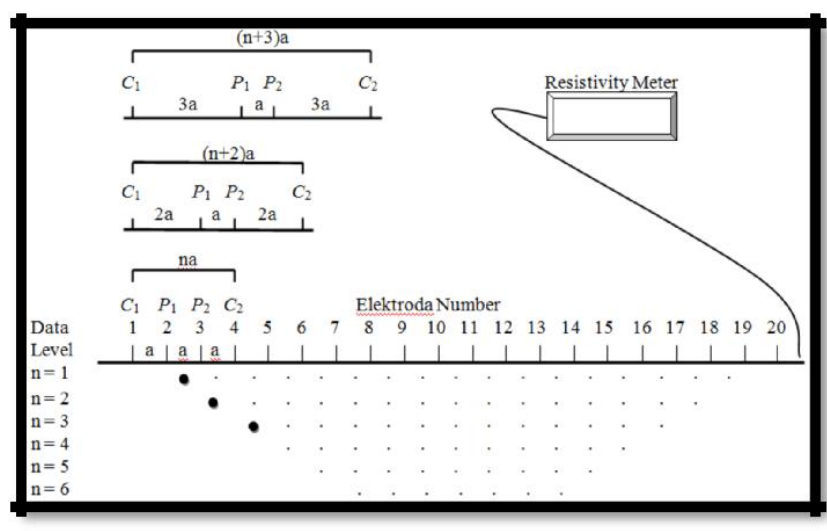

Gambar 5. Pengaturan elektoda konfigurasi Wenner-Schlumberger

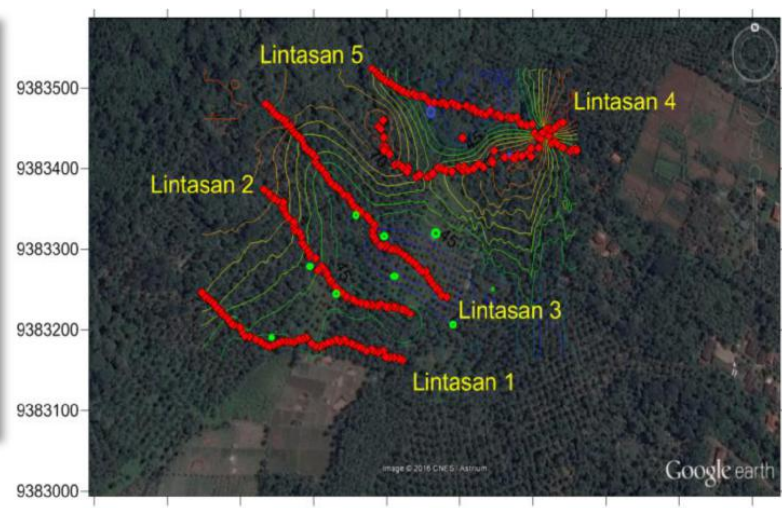

$\begin{array}{llllllllll}514900 & 515000 & 515100 & 515200 & 515300 & 515400 & 515500 & 515600 & 515700 & 515800\end{array}$

Gambar 6. Lintasan pengukuran dan posisi manifestestasi Google Earth

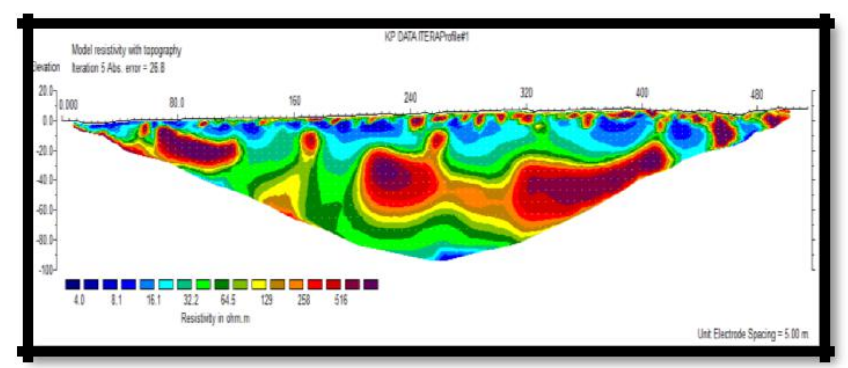

Gambar 7. Penampang 2D dengan topografi Res2dinv

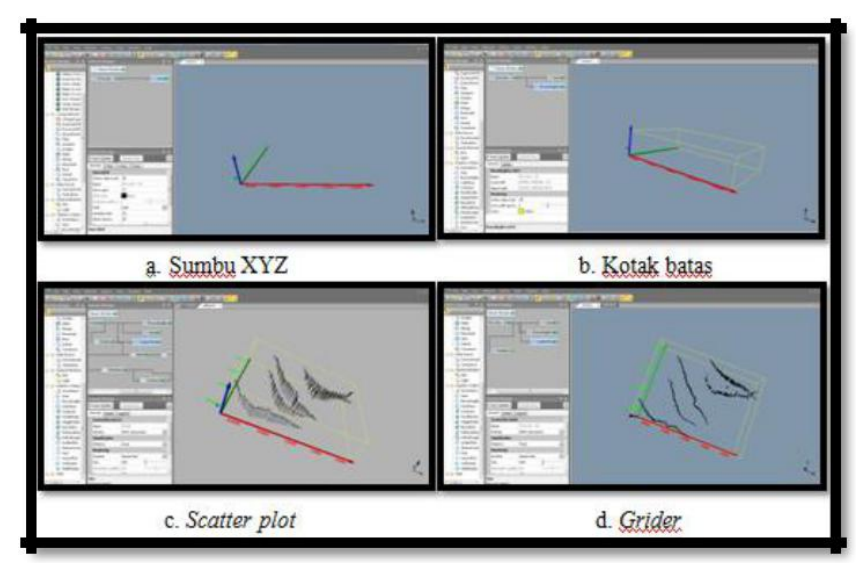

Gambar 8. a) Sumbu XYZ, b) Kotak batas, c) Scatter plot,d) Grider 


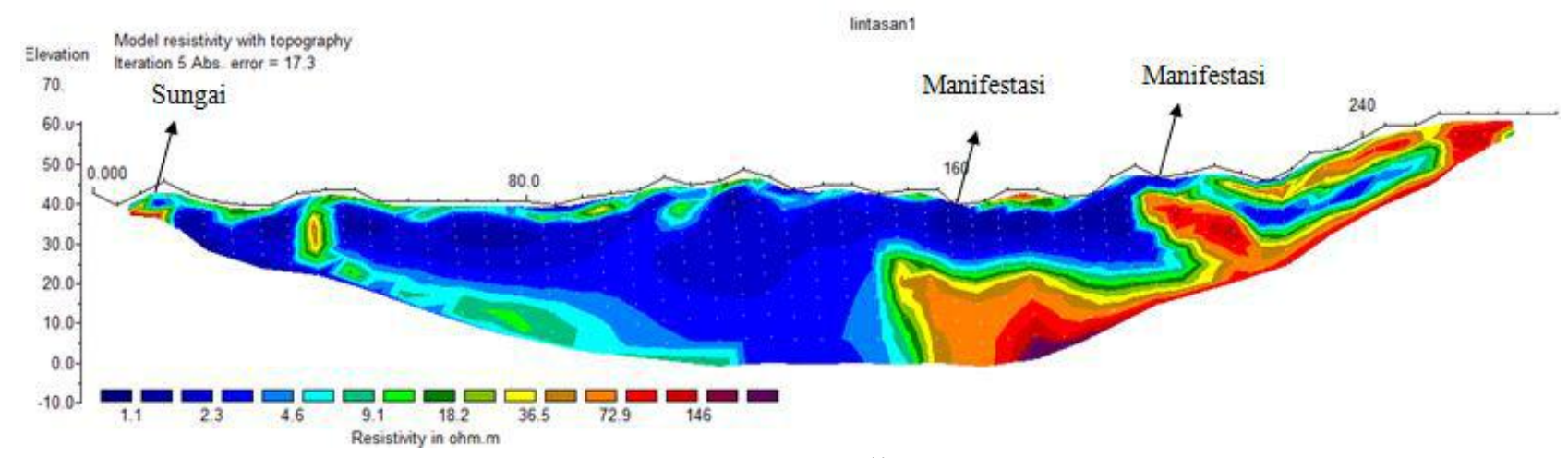

Gambar 9. Penampang 2D lintasan 1

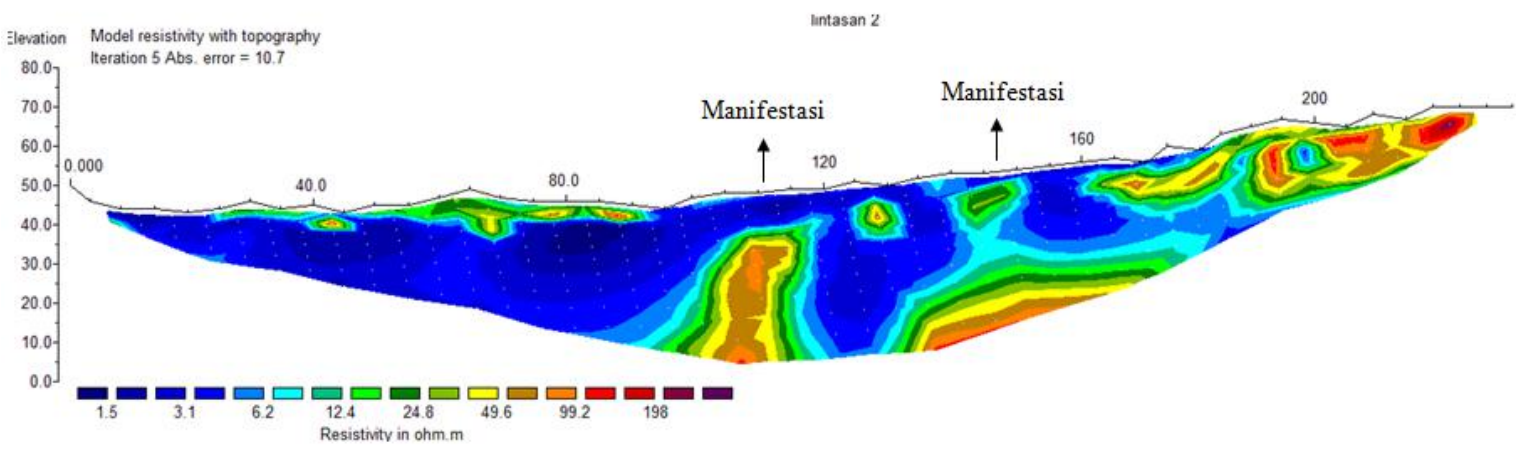

Gambar 10. Penampang 2D lintasan 2

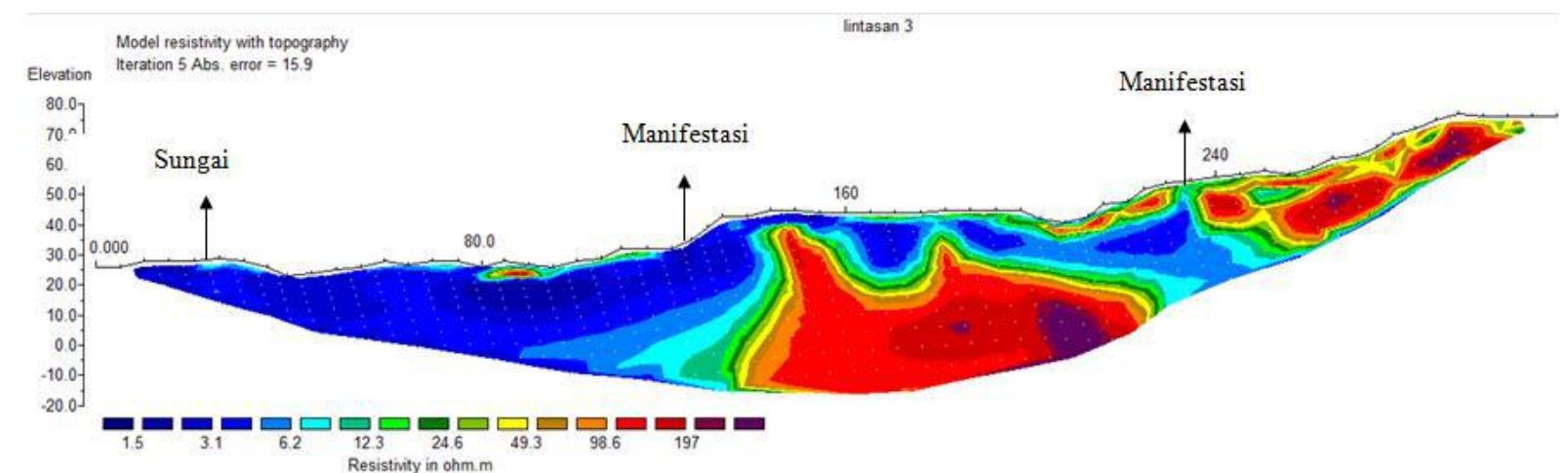

Gambar 11. Penampang 2D lintasan 3

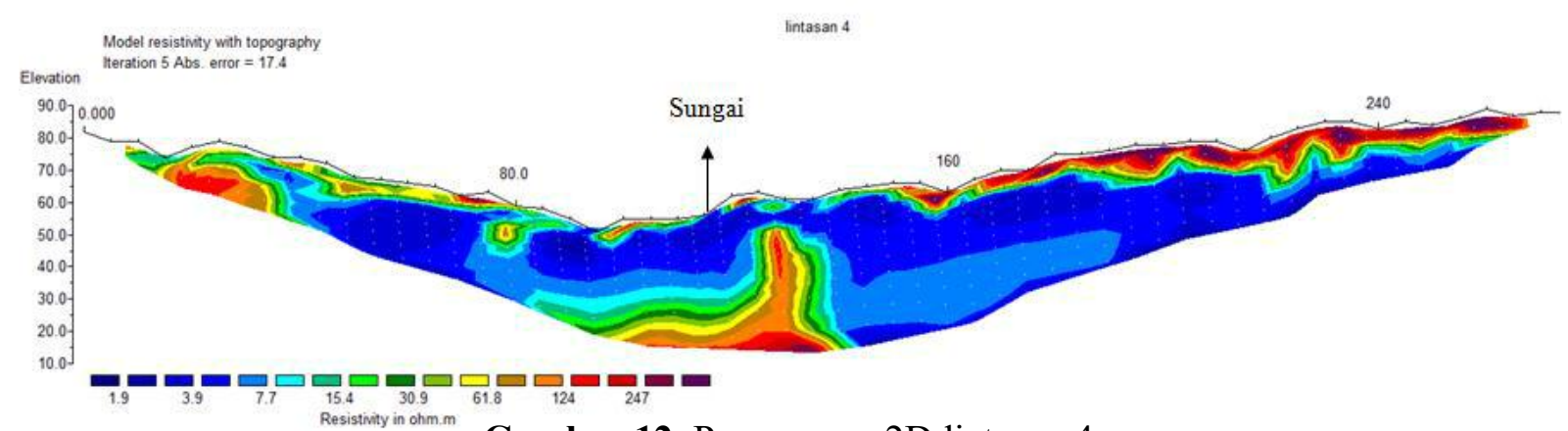

Gambar 12. Penampang 2D lintasan 4 


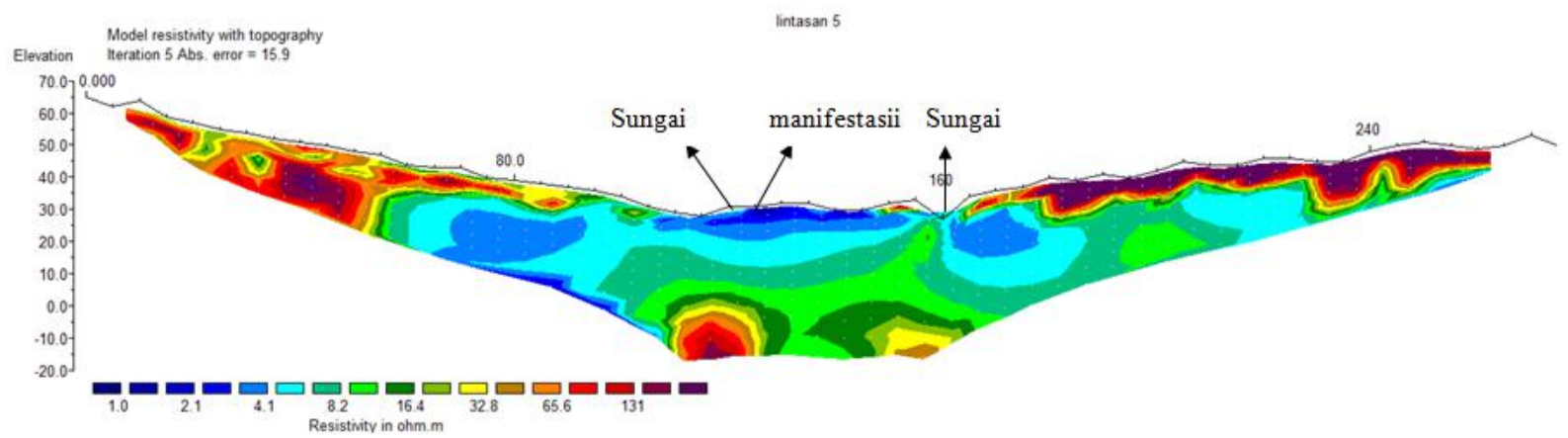

Gambar 13. Penampang 2D lintasan 5
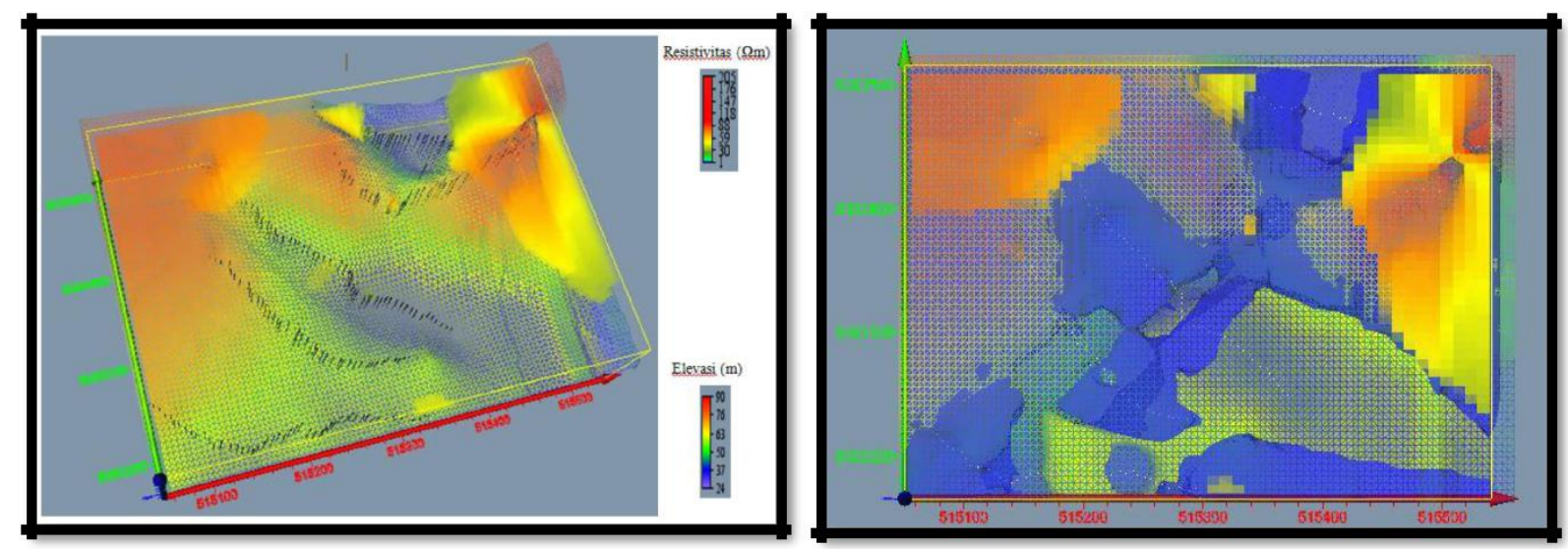

Gambar 14. Posisi lintasan pengukuran

Gambar 15. Sebaran fluida air panas di dalam model 3D
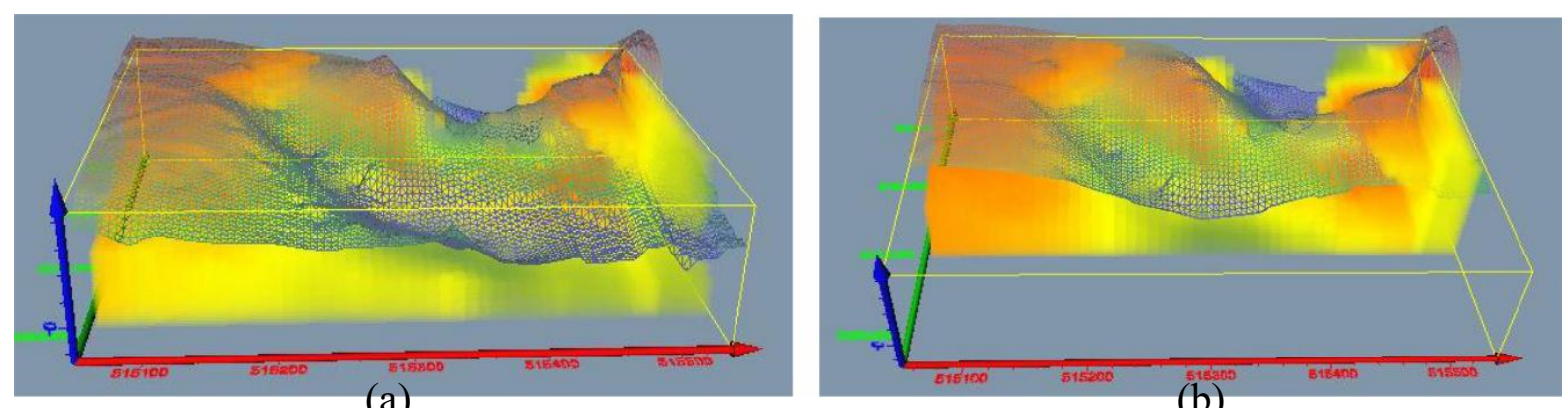

(a)

(b)

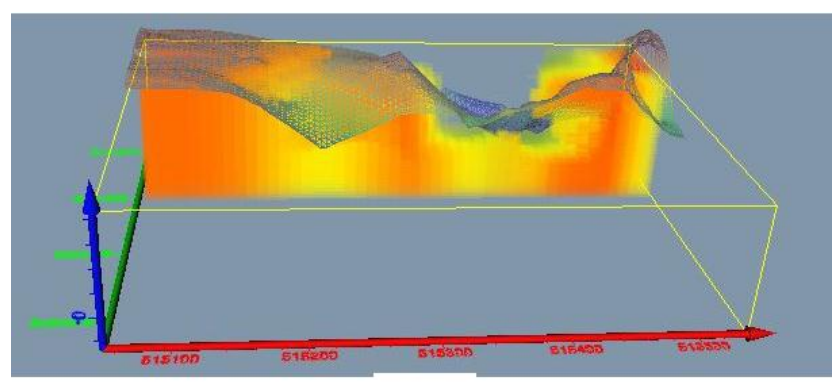

(c)

Gambar 16. (a) Pemotongan model reistivitas 3D UTM 9383200 (b)Pemotongan model resistivitas 3D di UTM 9383300 (c) Pemotongan model resistivitas 3D di UTM 9383400 